\title{
Türkiye ve Kazakistan Öğretmen Adaylarının Dijital Okuryazarlık Düzeylerinin İncelenmesi
}

\author{
Doç. Dr. Mehmet Arif Özerbaş \\ Gazi Üniversitesi, Gazi Eğitim Fakültesi \\ ozerbas@gazi.edu.tr \\ Doç. Dr. Aliya Kuralbayeva² \\ Hoca Ahmet Yesevi Üniversitesi, Beşeri Bilimler Fakültesi \\ aliya.kuralbayeva@ayu.edu.kz
}

DOI: $10.21666 /$ muefd.314761

\begin{abstract}
$\ddot{O z e t}$
Bu çalışmanın amacı, Türkiye ve Kazakistan'daki ögrretmen adaylarının dijital okuryazarlık düzeylerini ortaya koymak ve belirli değişkenlere göre karşılaştırmalı olarak incelemektir. Araştırma, ilişkisel tarama modeline uygun olarak gerçekleştirilmiştir. Araştırmanın evrenini 2015-2016 öğretim yllında Türkiye ve Kazakistan'da ögrrenimlerine devam eden ilkokul ve ortaokul ögretmen adayları oluşturmaktadır. Örneklemini ise, 2015-2016 öğretim yllında Türkiye'de Gazi Üniversitesi, Kazakistan'da ise Ahmet Yesevi Üniversitelerinin Ĕgitim Fakültelerinde ǚ ve dördüncü sinıfa devam eden toplam 601 ilkokul ve ortaokul ögrretmen adaylart oluşturmaktadır. Araștırmada veri toplama aracı olarak Acar, 2014 tarafindan geliştirilen Dijital Okuryazarlık Değerlendirme Ölçeği kullanılmıştır. Yapılan analizler sonucunda şu sonuçlara ulaşılmıştır; Cinsiyet değişkenine göre her iki ülkede de kadın ögretmen adayların erkek öğretmen adaylarından daha kalabalık olduğu saptanmıştır. Sinıf değişkenine göre araștırmaya katılan ögretmen adaylarının Türkiye'de 3 ve 4. sinıf sayıları benzerken Kazakistan'da dördüncü sinıfların daha kalabalık oldukları görülmüştür.

Anahtar sözcükler: Okuryazarlık, Dijital Okuryazarlık, Öğretmen Adayl.

\section{A Review of Digital Literacy Levels of Future Primary-School and Secondary-School Teachers in Turkey and Kazakhstan}

\begin{abstract}
The purpose of this scientific work is to identify the digital literacy levels of future teachers of Kazakhstan and Turkey and investigate comparatively depending on the definite changes. The research work was prepared in accordance with a comparative study model. The basis of the study is the future primary school and secondary school teachers of Academic Year 2015-2016 in Kazakhstan and Turkey. The total number of 601 future primary school and secondary school teachers studying in the pedagogy faculties of Gazi University in Turkey and Akhmet Yassawi University in Kazakhstan in Academic Year 2015-2016 were taken as an example for this study. The latest digital literacy assessment (review) dimension (system, method) of Acar 2014 was used as a means of collecting data. As a result of the analyses, we came to the conclusion: in terms of sex peculiarity, the number of female teachers was more than that of male teachers in both countries. In terms of the year specifics, a similarity between the numbers of third-and fourth-year future teachers was defined in Turkey, while the greater number of fourth year future teachers in Kazakhstan was identified.
\end{abstract}

Key words: Literacy, Digital System literacy, Future Teachers.

Dijital okuryazarlık; hem bireyin bilgi iletişim teknolojilerini etkin olarak öğrenmesini kapsarken hem de bu teknolojilerle kişisel gelişimine katkı sunacak, hayatın herhangi bir bağlamında problemini çözecek, toplumsal katılım ve üretimini destekleyecek şekilde teknolojilerin güvenli, yasal ve ahlaki kullanımıla ilgili yeterliklerini ifade eder. Digital literacy', yani 'dijital okuryazarlık' olarak adlandırılan terim, efektif ve ciddi bir şekilde internet üzerinden araştırma yapmak, değerlendirmek ve çeşitli dijital teknolojilerden yararlanarak bilgi toplamak anlamına gelir. Yaşam boyu öğrenmenin önemini artırması, bilgisayar ve diğer teknolojik araçların hakimiyeti dijital okuryazarlık kavramının önemli hale gelmesine zemin oluşturmuştur. Teknolojinin yaşamımızda yerini sağlamlaştırması onu nasıl, neden ne kadar kullanmamız gerektiğini ve ondan faydalanmamız gerçeğini doğurmuştur.

\footnotetext{
\$ Bu araştırmada elde edilen bulgular 12-14 Mayıs 2016 tarihleri arasından düzenlenen "XV. Uluslararası Sınıf Öğretmenliği Eğitimi Sempozyumu” adlı sempozyumda sözlü bildiri olarak sunulmuştur
} 
Alanyazın incelendiğinde teknoloji kullanma becerisi 3 farklı seviyesi olduğu görülmektedir. Bunlar bilgi, problem çözme ve ortak bilgi inşa edebilme becerisidir.

Dijital yeterlilik gerektiren bu becerilerin teknolojik, bilişsel ve etik boyutlarda birlikteliğinin vurgulanması gerekir. Dijital yeterliliğin temelini oluşturan bu 3 boyut içi dolu, ahlaki dayanağı olan ve teknik boyutta bir yeterliliğin birleşmesi anlamına gelmektedir. Bireylerin kaliteli, güvenli bir teknolojik yaşantı elde edebilmesi için bu 3 boyutun kesişim alanında bulunması gerekmektedir. Bu durum dijital okuryazarlığın önemini doğurmuştur (Carvani, Cartelli, Fini ve Ranieri ,2008). Dijital okuryazarlık kavramını 1997 yılında ilk kez paylaşan isim Paul Gilster olmuş ama 'Digital Literacy' adlı kitabında dijital okuryazarlığın tek bir tanımını yapmaktan kaçınmıştır. Dijital okuryazarlık geleneksel okuryazarlığın bir alternatifi değil ama ona katkıda bulunan bir uzantısıdır ve çağdaş dünyada çalışma, öğrenme, sosyalleşme için gereklidir (Churcill, Oakley \& Churchill, 2008). Martin (2008)‘e göre ise, dijital okuryazarlık; dijital araç kullanabilmek için bireylerin farkındalık, tutum ve yeteneklerini geliştirmesi, dijital kaynaklara erişmesi, eriştiklerini değerlendirebilmesi, entegre, analiz ve sentez edebilmesi, yeni bilgi oluşturabilmesi, kişilerle iletişim kurabilmesi, yapıcı sosyal eylemlerle bu süreci sosyal hayatına yansıtabilmesi şeklinde tanımlamış ve dijital okuryazarlığı; dijital yeterlilik, dijital kullanım ve dijital dönüşüm olarak 3 ayrı düzeyde değerlendirmiştir.

Birçok boyutta toplumsal değişimin gerekliliği olan dijital okuryazarlık sadece günlük hayatımızda basit değişiklikler yapmakla kalmamış fikir dünyamızı, ilişkilerimizi teknik bileşenlerimizi de değişmiştir. Rantala ve Suoranta (2008) dijital okuryazarlık kavramına başka bir pencereden bakarak; insanlığın gelişme ve kalkınma tarihinin son başarısı olarak kendisini temsil ettiğini, kamusal alanda cazip bir imaja sahip olduğunu söylemektedirler. Akademik alanda dijitalleşme sadece kölelikten ve yoksulluktan kurtulma değil, aynı zamanda küresel bir yenilik ve yaratıcılık gibi önemli soru işaretlerine çözüm getirdiğini ifade etmişlerdir. İnsanlığın yaşam kalitesini artırarak, dijitalleşen yeni iş sahalarına ve yeni mal üretmek için yardımcı bir unsur olarak görüldüğünü belirterek, dijital okuryazarlığa ekonomik bir yatırım olarak bakmanın da abartı olduğu düşünmektedirler. Efımova ve Grudin (2008) yaptıkları çalışmada dijital okuryazarlığın ekonomik boyutuna dikkat çekerek, iletişim teknolojilerinin özellikle gençler üzerinde etkili olduğunu, gençlerin dünya ve dünyadaki akranları hakkında bilgi sahibi olmak için iletişim teknolojilerini kullandıklarını söylemişlerdir.

Cep telefonu kullanma yaşının gittikçe düştügünü, iletişim teknolojilerinin maliyet bakımında onları zorlasa bile bu zorluğu aşmak için yeterli motivasyona sahip olduklarını dile getirmişlerdir. Bu gençler okullarından mezun olup iş hayatına başladıklarında dijital okuryazarlık adına o güne kadar biriktirmiş oldukları bilgileri beraberinde götürürken sistem içinde var olan yaşlı ve orta yaşlı bireylerin bu becerilerden uzak kaldıklarını belirtmişlerdir. Bu yüzden şirketler uzun süre dijital gelişmelere direnç göstermişlerdir. Önceki teknolojilere göre daha hızlı web tabanlı teknolojilerinin gelişmesi yazılım şirketlerinin önem kazanması, ucuz ve verimli yazılımlarının kullanılması şirketleri bu dijital havuzun içine dahil etmiştir. Artık ekonomik ve siyasi bağlamda geniş etkileri olduğu bilinen dijital okuryazarlığın sosyal yaşam üzerindeki etkileri yadsınamaz bir boyut kazanmıştır.

Son dönemlerde, dijital yetkinliğin çocuklara ve gençlere öğrenmeleri için daha fazla içerik ve motive edici bir ortam sağladığını, ve gelecekte bilgi toplumunun interaktif katılımcıları olan öğrencilerin hedeflerine ulaşmak için daha çok dijital medya kullanacaklarını belirtmiştir. Bu bağlamda değişen sınıflar içinde, geleneksellikten uzaklaşan ders araç-gereçleri etrafında gelişmeye direnen dijital kimlikten sıyrılmış öğretmen ve öğrenciler olması düşünülemez hal almıştır. Bu gün dijital toplumu oluşturan bireyler olmamız vatandaşlık kavramını dijital vatandaşlığa dönüştürmüştür (Soby,2008). Dijital yaşamda bireylerin günlük hayatlarında gerçekleştirdikleri eylemlerin doğru, güvenli, etik olması gerekmektedir. Bilgisayar kullanan, internetten alış-veriş yapan, ekrandan okuyan, elektronik yöntemlerle haberleşen, ödeme işlemlerini, hesap takiplerini internet üzerinden yapan ebeveynlerin, ders materyallerini dijital ortamda hazırlayan ve sunan öğretmenlerin, küçük yaşta bilgisayar akıllı telefon vb. araçlarla tanışan öğrencilerin oluşturduğu eğitim dünyasında alınması gereken önlemler ve kaliteli bir süreç olmalıdır. Baştuğ ve Keskin (2013) teknolojik ürünlerin gençlerin yaşamlarını çevrelediğini bu nedenle de okuma-yazma eylemlerinde tercih edilen materyallerde değişiklik meydana geldiğini belirtmişlerdir.

Bunun yanında birer dijital vatandaş olarak sanal ortamda geride bıraktığımız; herkes tarafından görülebilen, depolanabilen, paylaşılabilen bilgilerimizin olması dijital ayak izi kavramına da dikkat çekmektedir. Bireylerin dijital ortamda karşılaştığı bu sorunlara çözüm bulabilmesi, dijital yaşam 
içerisinde kaliteli bir süreç geçirebilmesi için iyi bir dijital okur-yazar olmaları gerekmektedir. Aytuna ve Tokgöz (2013) yaptıkları araştırmada araştırmaya katılan çocukların neredeyse tamamının interneti sadece oyun oynama için kullandıklarını ve hatta sosyal ağları bile önce oyun amaçlı sonra iletişim amaçlı kullandıklarını dile getirmişlerdir. Bunun için bireylerin kendilerini tek boyutluluktan kurtararak sahip oldukları kaynakların, araçların, imkanların çok boyutluluğundan yararlanarak hareket etmelilerdir. Bilgisayarı sadece internete girmek için, televizyonu sadece herhangi bir programın izlenmesi için, telefonu sadece arama yapmak için kullanmak günümüz dünyasında bir yetersizliktir. Dijital aletlerin birbiri yerine kullanılabilirliği ve hemen hemen hepsinde olan internet erişimi insanları dijital yeterlilik kaygısına sürüklemektedir.

Bu kaygı beraberinde güncellenmiş bilgiye ulaşamama, teknolojiye hakim olamama, dijital aletleri güvenli kullanamama ve bu aletlerden üst seviyede verim alamama gibi problemler doğurmuştur. $\mathrm{Bu}$ bağlamda bireylerin içine bırakıldığı dijital yaşamda bocalamamaları, yanlış bir yönde ilerlememesi için dijital okuryazarlık alanında araştırmaların artırılması gerekmektedir. B. Timur, Timur ve Akkoyunlu (2014) daha önce yapılan çalışmaların ülkemizde internet kullanımının bilinçli olmadığını nicel bakımdan artış görülürken aynı artışın nitel bakımında görülmediğini ve buradaki en büyük görevin eğitim kurumları ve öğretmenlere düştüğünü dile getirmişlerdir. Hem bireyler hem de ülkeler arasındaki sayısal uçurumun azaltılması için eğitime teknolojinin entegre edilmesi, bireylere teknolojiyi neden, nasıl kullanılacağının öğretilmesi gerekmektedir. Kişilere bu dijital yetkinliği kazandıracak olan öğretmenlerinde önce kendilerinin bu yetkinliğe sahip olması gerekmektedir. Öğretmenlerin mesleklerine ilişkin yerine getirmeleri gereken görev ve sorumluluklar için en iyi düzeyde eğitim almalarının yanında, eğitim süreçlerinde öğrendiklerini uygulayabileceklerine dair inançlarının yeterli düzeyde olması önem taşımaktadır. Görev ve sorumluluklarını yerine getirebileceğine inanan öğretmenlerin, mesleki başarısı da yüksek olmaktadır. Öğretmenlerin yaşama göre kendilerini şekillendirmeleri, çocukların ihtiyaçlarına cevap verecek güçte olabilmeleri için; dijital okuryazarlık hakkında bilgileri, dijital okuryazarlık düzeyleri, dijital okuryazarlığa ilişkin görüşleri önemli bir sorundur. Bahsedilen bu sorunlar içerisinde yer alan dijital okuryazarlığa ilişkin Türkiye ve Kazakistan'da öğretmenlik eğitimlerine devam eden öğretmen adaylarının dijital okur-yazarlık düzeylerinin ne olduğu bu araştırma problemini oluşturmaktadır.

\section{Amaç}

$\mathrm{Bu}$ araştırmanın genel amacı; Türkiye ve Kazakistan ülkelerindeki öğretmen dijital okuryazarlıklarına ilişkin düzeylerini ortaya koymak ve belirli değişkenlere göre karşılaştırmalı olarak incelemektir. Bu genel amaç çerçevesinde aşağıdaki sorulara cevap aranmıştır:

1. Ülkelere göre öğretmen adaylarının kendilerine ilişkin dijital okuryazarlık düzeyleri nedir?

2. Cinsiyete göre öğretmen adaylarının dijital okuryazarlık düzeyleri arasında anlamlı farklılık göstermekte midir?

3. Okuduğu sınıfa göre anlamlı farklılık göstermekte midir?

4. Öğretmenlik branşına göre anlamlı farklılık göstermekte midir?

\section{Araştırmanın Modeli}

\section{Yöntem}

$\mathrm{Bu}$ araştırma, ilişkisel tarama modeline uygun olarak planlanıp gerçekleştirilmiştir. Araştırmanın evrenini 2015-2016 öğretim yılında Türkiye ve Kazakistan öğrenimlerine devam eden 601 ilkokul ve ortaokul öğretmen adayları oluşturmaktadır. Örneklemini ise, Türkiye'de Gazi Üniversitesi Eğitim Fakültesi İlköğretim Bölümü Okul Öncesi Öğretmenliği, Sınıf öğretmenliği, Sosyal Bilgiler öğretmenliği ve Matematik öğretmenliği Anabilim Dalı lisans programında 3. Ve 4. Sınıfta öğrenim gören 363 öğretmen adayı oluşturmaktadır. Kazakistan'da ise Hoca Ahmet Yesevi Üniversitesi Eğitim Fakültesi İlköğretim Bölümü Okul Öncesi Öğretmenliği, Sınıf öğretmenliği ve Sosyal Bilgiler öğretmenliği Anabilim Dalı lisans programı 3. ve 4. sınıfta öğrenim gören toplam 218 öğretmen aday1 oluşturmaktadır.

\section{Çalışma Grubu}

Araştırma kapsamına alınan öğretmenlerin sosyo demografik özelliklere göre frekans ve yüzdelik dağılımları Tablo 1' de verilmiştir. 
Tablo 1. ğretmenlerin sosyo demografik özelliklere göre frekans ve yüzdelik dağılımları

\begin{tabular}{|c|c|c|c|c|}
\hline & \multicolumn{2}{|c|}{ Türkiye } & \multicolumn{2}{|c|}{ Kazakistan } \\
\hline Boyutlar & $\mathrm{N}$ & $\%$ & $\mathrm{~N}$ & $\%$ \\
\hline Ülke & 383 & 63,73 & 218 & 36,27 \\
\hline \multicolumn{5}{|l|}{ Cinsiyet } \\
\hline Kadın & 339 & 56,41 & 196 & 32,61 \\
\hline Erkek & 44 & 7,32 & 22 & 3,66 \\
\hline \multicolumn{5}{|l|}{ Sinıf } \\
\hline 3.sinif & 187 & 31,11 & 77 & 12,81 \\
\hline 4.Sinif & 196 & 32,61 & 141 & 23,46 \\
\hline \multicolumn{5}{|l|}{ Bölüim } \\
\hline Matematik & 59 & 9,82 & & \\
\hline OÖE & 82 & 13,64 & 90 & 14,98 \\
\hline Sınıf Öğretm & 214 & 35,61 & 71 & 11,81 \\
\hline Sos1 Bilg Öğrt & 28 & 4,66 & 30 & 4,76 \\
\hline \multicolumn{5}{|l|}{ Bilgisayar } \\
\hline Var & 309 & 51,41 & 190 & 31,61 \\
\hline Yok & 74 & 12,31 & 28 & 4,66 \\
\hline \multicolumn{5}{|l|}{ İnternet } \\
\hline Var & 297 & 49,42 & 171 & 28,45 \\
\hline Yok & 86 & 14,31 & 47 & 7,32 \\
\hline
\end{tabular}

Tablo 1'deki Öğretmen adaylarının demografik özellikleri incelendiğinde; \%63.73'nün Türkiye'de, \%36.27'sinin Kazakistan'da öğrenimlerine devam ettiği, \%65.2'sinin üçüncü sinıfta, \%34.8'inin dördüncü sınıfta öğrenim gördüğ̈̈; \%89.02'sinin kadın, \%10.8'inin erkek olduğu; \%9.8'sinin matematik bölümünde, \%28.4'ünün okulöncesi eğitim bölümünde, \%47.8'inin sınıf öğretmenliği bölümünde ve \%8.7'inin sosyal bilgiler öğretmenliğinde olduğu belirlenmiştir. Öğretmen adaylarının, \%82.3'ünün bilgisayara sahip olduğu, \%18.3'ünün ise bilgisayarının olmadığı, \%77,8'inin interneti kullandığı, \%23.3'ünün interneti kullanamadıkları saptanmıştır. Cinsiyet değişkenine göre her iki ülkede de kadın öğretmen adayların erkek öğretmen adaylarından daha kalabalık olduğu saptanmıştır. Sınıf değişkenine göre araştırmaya katılan öğretmen adaylarının Türkiye'de 3 ve 4. sınıf sayıları benzerken Kazakistan'da dördüncü sınıfların daha kalabalık oldukları görülmüştür. Bölüm değişkeninde Türkiye'de sınıf öğretmenleri yoğunken Kazakistan'da OÖEÖ daha yoğundur. Bilgisayara sahip olma durumu her iki ülkede de benzer olduğu ve çoğunluğun bilgisayarı olduğu tespit edilmiştir. İnternet alt yapısı ve bağlanma durumunda Türkiye gelişmişlik düzeyine göre daha fazla bağlantıya sahip olduğu görülmüştür. İnterneti kullanma durumunda her iki ülkede de araştırmaya katılma oranların doğrultusunda "günlük yaşamda çok yoğun olmasa da kullanıyorum" seçeneği daha baskın çıkmıştır. Sürekli internet bağlantısına sahip olma durumu öğretmenlerin dijital okuryazarlık görüşleri üzerinde etkili bir değişkendir. Sürekli internet bağlantısına sahip 
öğretmenler dijital okuryazarlık bakımından kendini daha yeterli hissetmektedir. Bahar, Uludağ ve Kaplan (2009) ilköğretim öğretmenlerinin bilgisayar ve internet tutumlarını inceledikleri çalışmalarında evlerinde sürekli internet bağlantısı olan öğretmenlerin bilgisayara ilişkin tutumlarında anlamlı fark bulurken internete ilişkin tutumlarında anlamlı bir fark bulamamışlardır. İnternet kullanma sıklığı öğretmenlerin dijital okuryazarlık düzeyleri üzerinde etkili bir değişkendir. İnterneti günlük hayatında hiç kullanmayanlar dışında öğretmenlerin ölçekten aldıkları ortalama puanlar doğrusal ilerlemiş ve internet kullanma sıklıkları arttıkça kendilerini daha yeterli hissetmişlerdir. Usta, Bozdoğan ve Yıldırım (2007) sınıf öğretmeni adaylarının internet kullanımına ilişkin yaptıkları çalışmada haftalık daha uzun süre internet kullanan öğretmen adaylarının internet kullanımına ilişkin tutum puanlarını diğer öğretmen adaylarına göre daha yüksek bulmuştur. Menzi, Çalışkan ve Çetin (2012) öğretmen adaylarının teknoloji yeterliklerini çeşitli değişkenler bakımından inceledikleri çalışmalarında interneti daha sık kullanan öğretmen adaylarının diğerlerine göre kendilerini teknoloji alanında daha yeterli gördükleri sonucuna ulaşılmıştır. İnternete bağlanmak için tercih edilen teknolojilerde Türkiye'de "dizüstü bilgisayar ve cep telefonları" ilk sırayı alırken, Kazakistan'da "cep telefonları" ilk sırada çıkmıştır. Bu sonuçlar ülkelerin gelişmişlik düzeylerine göre doğal bir dağılım olarak yorumlanmıştır.

\section{Veri Toplama Aracı}

Öğretmenlerin kendilerine, anne ve babaların kendilerine ve çocuklarına ilişkin dijital okuryazarlık değerlendirmelerini saptamak için yapılan bu araştırmada Acar ve Şimşek (2015) tarafindan geliştirilen ' 'Dijital Okuryazarlık Değerlendirme Ölçeği' kullanılmıştır. Hem ölçeğin bütünü için hem de alt ölçeklerin güvenirliğinin belirlenmesi amacıyla iç tutarlık yöntemlerinden olan Cronbach $\alpha$ değerleri hesaplanmıştır. Ölçek kendi içerisinde beş boyuttan oluşmaktadır. Bu boyutlar; 16 maddeden oluşan farkındalık alt boyutu için $.968,9$ maddeden oluşan bağlamsal kullanım alt boyutu için $.958,6$ maddeden oluşan güvenli katılım alt boyutu için $.928,4$ maddeden oluşan dijital kimlik yönetimi alt boyutu için .908 ve 5 maddeden oluşan temel araç ve ortam bilgisi alt boyutu için .899 olarak bulunmuştur. Hesaplanan Cronbach $\alpha$ değerleri; 40 maddeden oluşan ölçeğin bütünü için .980,olarak hesaplanmıştır. $\mathrm{Bu}$ değer ölçeğin yüksek derece de güvenilir olduğunu göstermektedir. Bu araştırma için de tekrardan güvenilirlik değerleri hesaplanmıştır. Çalışma kapsamında da Dijital Okuryazarlık Değerlendirme Ölçeği (DOYDÖ)'nin iç tutarlık katsayısının belirlenmesi için Cronbach'ın $\alpha$ korelasyon katsayısı hesaplanmıştır. Bunun nedeni; birleşik ölçmelerde $\alpha$ katsayısı birleşik ölçmeye ait gözlenen puanların gerçek puanlarla korelasyonunu vermektedir. $\mathrm{Bu}$ nedenle $\alpha$ bir güvenirlik katsayısı olarak kullanılmaktadır. Bu durumda $\alpha$ katsayısı bileşenlere ait puanların birleşik test puanlarıyla tutarlılı̆̆ının bir ölçüsüdür (Baykul, 2000). Buradan anlaşılacağı üzere $\alpha$ katsayısı bir ölçekteki maddelerin ölçeğin tamamıyla ölçülmek istenen özelliğe ilişkin alt maddelerin birbirleriyle olan tutarlılı̆̆ının bir göstergesidir. Bunun için ölçek çalışmada adı geçen her iki ülkede de Eğitim Fakültelerinde öğrenim gören toplam 204 öğrenciye uygulanarak Cronbach $\alpha$ değerleri hesaplanmıştır. Ölçek orjinalin de olduğu gibi kendi içerisinde beş boyut oluşturmuştur. Sadece bazı boyutlarda kat sayılarda küçük değişiklikler göstermiş̧tir. Yapılan analiz sonucunda ölçeğin tamamına ilişkin güvenirlik katsayısı $\alpha=0.82$, olarak hesaplanmıştır. Ölçeğin alt boyutlarında ise: 16 maddeden oluşan farkındalık alt boyutu için $.810,9$ maddeden oluşan bağlamsal kullanım alt boyutu için .853, 6 maddeden oluşan güvenli katılım alt boyutu için .826, 4 maddeden oluşan dijital kimlik yönetimi alt boyutu için .921ve 5 maddeden oluşan temel araç ve ortam bilgisi alt boyutu için .763 olarak bulunmuştur. Buna göre ölçeğin ideal güvenirlik değerine sahip olduğu kabul edilmiştir.

\section{Verilerin Analizi}

Elde edilen verilerin analizinde; öğretmen adaylarına ilişkin demografik özelliklerin değerlendirilmesinde frekans ve yüzde gibi betimsel istatistikler kullanılmıştır. Gruplar arası farklılık incelenirken İkili Gruplarda t Testi, ikiden fazla gruplarda ise Tek Faktörlü ANOVA Testi uygulanmıştır. Tüm analizlerde anlamlılık düzeyi $\mathrm{p}=.05$ olarak alınmıştır. 


\section{Bulgular}

Türkiye ve Kazakistan ilkokul - ortaokul öğretmen adaylarının dijital okuryazarlık düzeylerini karşılaştırmak amacıyla yapılan araştırmadan elde edilen bulgular tablolar halinde sunulmuştur. Ülkelere göre öğretmen adaylarının kendilerine ilişkin dijital okuryazarlık düzeyleri; Tablo 2. Ülkelere Göre Öğretmen Adaylarının Dijital Okur Yazarlık Düzeyleri Puanlarının Ortalama ve Standart Sapma Değerleri ve ANOVA Sonuçlart

\begin{tabular}{|c|c|c|c|c|c|c|c|}
\hline Boyutlar & Ülke & $N$ & $\mathbf{x}$ & $S$ & $S d$ & $\mathbf{F}$ & $p$ \\
\hline \multirow[t]{2}{*}{ Toplam Puan } & Kazakistan & 218 & 121,01 & 20,33 & \multirow[t]{2}{*}{$1-596$} & \multirow[t]{2}{*}{210,294} & \multirow[t]{2}{*}{, 000} \\
\hline & Türkiye & 383 & 149,38 & 24,87 & & & \\
\hline \multirow[t]{2}{*}{ Farkındalık } & Kazakistan & 218 & 51,66 & 9,17 & $1-596$ & \multirow[t]{2}{*}{175,37} & \multirow[t]{2}{*}{,000 } \\
\hline & Türkiye & 383 & 63,25 & 11,11 & $1-596$ & & \\
\hline \multirow[t]{2}{*}{ Bağlamsal Kullanım } & Kazakistan & 218 & 27,66 & 5,95 & $1-596$ & \multirow[t]{2}{*}{176,252} & \multirow[t]{2}{*}{, 000} \\
\hline & Türkiye & 383 & 35,04 & 6,92 & $1-596$ & & \\
\hline \multirow[t]{2}{*}{ Güvenli Katılım } & Kazakistan & 218 & 14,81 & 3,22 & $1-596$ & \multirow[t]{2}{*}{130,477} & \multirow[t]{2}{*}{,000 } \\
\hline & Türkiye & 383 & 18,25 & 3,68 & $1-596$ & & \\
\hline \multirow[t]{2}{*}{ Dijital Kimlik } & Kazakistan & 218 & 11,42 & 2,77 & $1-596$ & \multirow[t]{2}{*}{185,231} & \multirow[t]{2}{*}{,000 } \\
\hline & Türkiye & 383 & 14,92 & 3,15 & $1-596$ & & \\
\hline \multirow{2}{*}{$\begin{array}{l}\text { Araç ve Ortam } \\
\text { Bilgisi }\end{array}$} & Kazakistan & 218 & 14,98 & 3,34 & $1-596$ & \multirow[t]{2}{*}{52,208} & \multirow[t]{2}{*}{,000 } \\
\hline & Türkiye & 383 & 17,03 & 3,49 & $1-596$ & & \\
\hline
\end{tabular}

Öğretmen adaylarının kendilerine ilişkin dijital okuryazarlık düzeyleri ülkeler değişkenine göre incelendiğinde; çalışmada kullanılan ölçeğin bütün alt boyutlarında anlamlı farklılık görülmektedir. Ölçeğin alt boyutlarının, Farkındalık [t(13,070)=.000, $\mathrm{p}<.05]$, Bağlamsal kullanım [t(13,213)=.000, $\mathrm{p}<.05]$, Güvenli katılım [t(11,493)=.000, $\mathrm{p}<.05]$, Dijital $\operatorname{kimlik}[\mathrm{t}(13,672)=.000, \mathrm{p}<.05]$, Araç ve ortam bilgisi $[\mathrm{t}(14,346)=.000, \mathrm{p}<.05]$, bütününde Türkiye'deki öğretmen adaylarının lehine anlamlı farklılığın olduğu görülmektedir. Diğer bir ifadeyle Türkiye'deki öğretmen adaylarının Kazakistan'daki öğretmen adaylarına göre daha dijital okuryazar oldukları görülmektedir. Bu bulgu ülkeler arasındaki sosyo- ekonomik ve teknolojik alt yapı düzeyinden kaynaklandığı söylenebilir.

Cinsiyete Göre Öğretmen Adaylarının Dijital Okur Yazarlık Düzeylerinin Karşılaştırılması Tablo 3. Cinsiyete Göre Öğretmen Adaylarının Dijital Okur Yazarlı Düzeylerinin Karşıllaştırılması

\begin{tabular}{|c|c|c|c|c|c|c|c|}
\hline Boyutlar & Cinsiyet & $N$ & $\mathbf{x}$ & $S$ & sd & $\mathbf{t}$ & $p$ \\
\hline \multirow[t]{2}{*}{ Farkındalık } & Kadın & 535 & 58,6 & 11,81 & & & \\
\hline & Erkek & 66 & 61,8 & 11,94 & 596 & 2,036 & ,034 \\
\hline \multirow[t]{2}{*}{ Bağlamsal Kullanım } & Kadın & 535 & 32,1 & 7,46 & & & \\
\hline & Erkek & 66 & 34,2 & 7,42 & 596 & 2,126 &, 001 \\
\hline \multirow[t]{2}{*}{ Güvenli Katılım } & Kadın & 535 & 16,8 & 3,86 & & 3,276 & \\
\hline & Erkek & 66 & 18,4 & 3,87 & 596 & &, 008 \\
\hline \multirow[t]{2}{*}{ Dijital Kimlik } & Kadın & 535 & 13,5 & 3,44 & & 2,650 & \\
\hline & Erkek & 66 & 14,7 & 3,43 & 596 & &, 000 \\
\hline \multirow[t]{2}{*}{ Araç ve Ortam Bilgisi } & Kadın & 535 & 16,0 & 3,49 & 596 & 4,975 & \\
\hline & Erkek & 66 & 18,3 & 3,60 & & &, 042 \\
\hline
\end{tabular}

Öğretmen adaylarının kendilerine ilişkin dijital okuryazarlık düzeyleri cinsiyet değişkenine göre incelendiğinde; çalışmada kullanılan ölçeğin bütün alt boyutlarında anlamlı farklılık görülmektedir. Ölçeğin alt boyutlarının, Farkındalık [t(2,036)=.034, p<.05], Bağlamsal kullanım $[\mathrm{t}(2,126)=.001, \mathrm{p}<.05]$, Güvenli katılım $[\mathrm{t}(3,276)=.008, \mathrm{p}<.05]$, Dijital kimlik $[\mathrm{t}(2,650)=.000, \mathrm{p}<$ $.05]$, Araç ve ortam bilgisi [t $(4,975)=.042, \mathrm{p}<.05]$, bütününde erkek öğretmen adaylarının lehine anlamlı farklılığın olduğu görülmektedir. Diğer bir ifadeyle erkek öğretmen adaylarının kadın öğretmen adaylarına göre daha dijital okuryazar oldukları söylenebilir. 
Sınıf Düzeylerine Göre Öğretmen Adaylarının Dijital Okur Yazarlık Düzeylerinin Karşılaştırılması

Tablo 4. Sinıf Düzeylerine Göre Öğretmen Adaylarının Dijital Okur Yazarlık Düzeylerinin Karşılaşttrılması

\begin{tabular}{|c|c|c|c|c|c|c|c|}
\hline Boyutlar & Sinif & $N$ & $\mathrm{x}$ & SS & $t$ & sd & $p$ \\
\hline \multirow[t]{2}{*}{ Farkındalık } & 3. sinif & 264 & 59,22 & 11,579 & ,370 & 596 & ,712 \\
\hline & 4.sinif & 334 & 58,86 & 12,095 & & & \\
\hline \multirow[t]{2}{*}{ Bağlamsal Kullanım } & 3. sinif & 264 & 33,57 & 7,251 & 3,542 & 599 & 000 \\
\hline & 4.sinif & 337 & 31,42 & 7,538 & & & \\
\hline \multirow{2}{*}{ Güvenli Katılım } & 3. sinif & 264 & 17,16 & 3,818 & 833 & 596 & ,405 \\
\hline & 4.sinif & 334 & 16,89 & 3,965 & & & \\
\hline \multirow[t]{2}{*}{ Dijital Kimlik } & 3. sinif & 264 & 13,67 & 3,411 & ,068 & 596 & ,946 \\
\hline & 4.sinif & 334 & 13,65 & 3,507 & & & \\
\hline \multirow[t]{2}{*}{ Araç ve Ortam Bilgisi } & 3. sinif & 264 & 16,20 & 3,588 &,- 515 & 599 & ,607 \\
\hline & 4.sinif & 337 & 16,35 & 3,577 & & & \\
\hline
\end{tabular}

Öğretmen adaylarının kendilerine ilişkin dijital okuryazarlık düzeyleri devam ettikleri sınıf değişkenine göre incelendiğinde; çalışmada kullanılan ölçeğin sadece bağlamsal kullanım [t(3,542)=.000, p< .05], alt boyutunda üçüncü sınıfa devam eden öğretmen adaylarının lehine anlamlı bir farklılık görülürken, diğer boyutlarda herhangi anlamlı bir fark görülmemektedir. Öğretmen adaylarının kendilerine ilişkin dijital okuryazarlık görüşlerinin incelenmesinde bir başka değişken olan bölümlere ait betimsel istatistikler aşağıda verilmektedir.

\section{Öğretmen Adaylarının Dijital Okur Yazarlık Düzey Ölçeği Puanlarının Bölümlere göre ANOVA Sonuçları}

Tablo 5. Öğretmen Adaylarının Dijital Okur Yazarlık Düzey Ölçeği Puanlarının Bölümlere göre ANOVA Sonuçları

\begin{tabular}{|c|c|c|c|c|c|c|c|}
\hline Boyutlar & $\begin{array}{l}\text { Varyansın } \\
\text { Kaynağı }\end{array}$ & $\begin{array}{c}\text { Kareler } \\
\text { Toplamı }\end{array}$ & Sd & $\begin{array}{c}\text { Kareler } \\
\text { Ortalaması }\end{array}$ & $\mathbf{F}$ & $\mathbf{P}$ & Anlamlı Fark \\
\hline \multirow[t]{3}{*}{ Farkındalık } & Gruplararas1 & 7090,190 & 3 & 2363,397 & 18,320 & 000 & SNF - OÖE \\
\hline & Gruplariçi & 77017,211 & 597 & 129,007 & & & SOB - OÖE \\
\hline & Toplam & 84107,401 & 600 & & & & MAT - OÖE, \\
\hline \multirow{3}{*}{$\begin{array}{l}\text { Bağlamsal } \\
\text { kullanım }\end{array}$} & Gruplararas1 & 2903,992 & 3 & 967,997 & 18,820 &, 000 & SNF - OÖE \\
\hline & Gruplariçi & 30706,005 & 597 & 51,434 & & & \\
\hline & Toplam & 33609,997 & 600 & & & & $\begin{array}{l}\text { MAT - OÖE, } \\
\text { SOB }\end{array}$ \\
\hline \multirow[t]{3}{*}{ Güvenli Katılım } & Gruplararas1 & 614,785 & 3 & 204,928 & 14,432 & 000 & SNF - OÖE \\
\hline & Gruplariçi & 8477,208 & 597 & 14,200 & & & \\
\hline & Toplam & 9091,993 & 600 & & & & MAT - OÖE \\
\hline \multirow[t]{3}{*}{ Dijital kimlik } & Gruplararas1 & 828,194 & 3 & 276,065 & 26,000 &, 000 & $\mathbf{S N F}-$ OÖE \\
\hline & Gruplariçi & 6338,880 & 597 & 10,618 & & & \\
\hline & Toplam & 7167,075 & 600 & & & & MAT - OÖE \\
\hline Araç ve Ortam & Gruplararas1 & 497,798 & 3 & 165,933 & 13,774 & ,000 & SNF - OÖE \\
\hline \multirow[t]{2}{*}{ Bilgisi } & Gruplariçi & 7191,826 & 597 & 12,047 & & & \\
\hline & Toplam & 7689,624 & 600 & & & & \\
\hline \multirow[t]{3}{*}{ Toplam Puan } & Gruplararas1 & 42588,397 & 3 & 14196,132 & 21,478 &, 000 & SNF - OÖE \\
\hline & Gruplariçi & 394589,569 & 597 & 660,954 & & & \\
\hline & Toplam & 437177,967 & 600 & & & & MAT - OÖE \\
\hline
\end{tabular}

Tablo 5.'de analiz sonuçlarında görüldüğü gibi öğretmen adaylarının kendilerine ilişkin dijital okuryazarlık görüşleri devam ettikleri bölümlere göre ölçeğin bütün boyutlarında anlamlı bir farkın olduğu görülmektedir. Ortaya çıkan bu farklılığın ölçeğin alt boyutları; Farkındalık düzeyinde $[\mathrm{F}(3,597)=18.320, \mathrm{p}<.01]$, bölümler arasındaki farklılıkların hangileri arasında olduğunu bulmak amaciyla yapılan post-hoc Scheffe testi sonuçlarına göre (SNF - OÖE, SOB - OÖE ve MAT - OÖE, SNF, SOB) öğretmen adayları arasında anlamlı bir fark bulunmaktadır. Ortalama puan farkları incelendiğinde Matematik öğretmen adaylarının diğer bütün branş öğretmen adaylarına göre dijital 
okuryazarlık düzeylerinin daha iyi olduğu görülmektedir. Bu bulgu Matematik öğretmen adaylarının görmüş oldukları öğretim programlarından kaynaklanmış şeklinde söylenebilir. Çünkü matematik öğretim programlarındaki derslerin çoğunluğu bilgisayar ortamında gerçekleştirilmektedir. Bağlamsal kullanım boyutunda $[\mathrm{F}(3,597)=18.820, \mathrm{p}<.01]$, bölümler arasındaki farklılıkların hangileri arasında olduğunu bulmak amaciyla yapılan post-hoc Scheffe testi sonuçlarına göre (SNF - OÖE, MAT - OÖE, SOB) öğretmen adayları arasında anlamlı bir fark bulunmaktadır. Ortalama puan farkları incelendiğinde Matematik öğretmen adayları ile Sınıf öğretmeni adaylarının diğer bütün branş öğretmen adaylarına göre dijital okuryazarlık düzeylerinin daha iyi olduğu görülmektedir. Güvenli katılım boyutunda $[\mathrm{F}(3,597)=14.432, \mathrm{p}<.01]$, bölümler arasındaki farklılıkların hangileri arasında olduğunu bulmak amacıyla yapılan post-hoc Scheffe testi sonuçlarına göre (SNF - OÖE, MAT - OÖE) öğretmen adayları arasında anlamlı bir fark bulunmaktadır. Ortalama puan farkları incelendiğinde yine Matematik öğretmen adayları ile Sınıf öğretmeni adaylarının diğer bütün branş öğretmen adaylarına göre dijital okuryazarlık düzeylerinin daha iyi olduğu görülmektedir. Dijital kimlik boyutunda $[F(3,597)=26.000, p<.01]$, bölümler arasındaki farklılıkların hangileri arasında olduğunu bulmak amacıyla yapılan post-hoc Scheffe testi sonuçlarına göre (SNF - OÖE, MAT - OÖE) öğretmen adayları arasında anlamlı bir fark bulunmaktadır. Ortalama puan farkları incelendiğinde yine Matematik öğretmen adayları ile Sınıf öğretmeni adaylarının diğer bütün branş öğretmen adaylarına göre dijital okuryazarlık düzeylerinin daha iyi olduğu görülmektedir. Araç ve ortam bilgisi boyutunda $[\mathrm{F}(3,597)=26.000, \mathrm{p}<.01]$, bölümler arasındaki farklılıkların hangileri arasında olduğunu bulmak amacıyla yapılan post-hoc Scheffe testi sonuçlarına göre (SNF - OÖE) öğretmen adayları arasında anlamlı bir fark bulunmaktadır. Ortalama puan farkları incelendiğinde Sınıf öğretmeni adaylarının Okul öncesi öğretmen adaylarına göre araç ve ortam bilgisi düzeylerinin daha iyi olduğu görülmektedir. Bu bulgular daha öncede değinildiği gibi Matematik ve Sınıf öğretmenliği öğretmen adaylarının görmüş oldukları öğretim programlarından kaynaklanmış şeklinde söylenebilir. Çünkü matematik ve sınıf öğretmenliği öğretim programlarındaki derslerin çoğunluğu bilgisayar ortamında gerçekleştirilmektedir.

\begin{abstract}
Sonuç
Öğretmen adaylarının yaşadıkları ülke değişkeni kendilerine ilişkin dijital okuryazarlık görüşleri üzerinde etkili bir değişkendir. Türkiye'deki öğretmen adayları dijital okuryazarlık bakımından kendilerini daha yeterli hissetmektedirler. Çünkü yapılan analiz sonuçlarında, Ülkelere göre öğretmen adaylarının dijital okuryazarlık düzeyleri puanlarının aritmetik ortalaması arasında ölçeğin bütün boyutlarında Türkiye'deki öğretmenler lehine anlamlı bir fark görülmüştür. Bu sonuç Türkiye'de teknoloji alt yapısının Kazakistan'a göre daha iyi olduğu ve öğretim programlarının uygulama ortamlarının daha elverişliliğginden kaynaklandığı söylenebilir.

Cinsiyete göre öğretmen adaylarının dijital okuryazarlık düzeylerinin karşılaştırıldığında, ölçeğin bütün boyutlarında erkek öğretmenler lehine olduğu görülmektedir. Bu durum erkek öğretmenlerin teknoloji kullanımı boyutunda daha iyi oldukları şeklinde değerlendirilmiştir. Sınıf düzeylerine göre öğretmen adaylarının dijital okuryazarlık düzeylerinin karşılaştırıldığında, ölçeğin bağlamsal kullanım hariç diğer bütün boyutlarında anlamlı bir farklılığın olmadığı görülmektedir. Cinsiyet, sınıf öğretmenleri için dijital okuryazarlık görüşleri bakımından ayırt edici bir değişken değildir. Seferoğlu ve Akbıyık (2005) ilköğretim öğretmenlerinin bilgisayara yönelik öz-yeterlilik algıları üzerine yaptıkları çalışmada kadın ve erkek öğretmenler arasında bilgisayar öz-yeterlik algısı açısından anlamlı bir fark bulunmadığını ifade ederek benzer sonuçlara ulaşmıştır. Kazu ve Erten (2014) öğretmen adaylarının sayısal yetkinlik düzeylerini inceledikleri çalışmalarında adaylarının cinsiyet değişkenine göre ölçeğin alt boyutlarında anlamlı farklılık bulurken genel sayısal yekinlik boyutunda anlamlı bir farkl111k elde edemeyerek benzer sonuçlara ulaşmışlardır. Gökçearslan ve Bayır (2011) öğretmen adaylarının sayısal yetkinlik düzeylerini inceledikleri çalışmalarında cinsiyet değişkenini ayırt edici bulmamışlardır. Bağlamsal kullanım boyutunda ortaya çıkan anlamlı farkın üçüncü sınıflar lehine olduğu görülmektedir. Bu sonuç üçüncü sınıfların ders programlarından ve dördüncü sınıfların KPSS'ye yönelik çalışmalarından kaynaklandığı şeklinde yorumlanabilir.

Bölüm değişkenine göre öğretmen adaylarının dijital okuryazarlık düzeylerinin karşılaştırıldığında, ölçeğin bütün boyutlarında Matematik ve Sınıf öğretmen adayları lehine olduğu görülmektedir. $\mathrm{Bu}$ sonuç Matematik ve sınıf öğretim programlarından ve interneti diğer bölümlerdeki öğretmen adaylarından daha çok kullandıklarından kaynaklandığı şeklinde yorumlanabilir. Usta, Bozdoğan ve
\end{abstract}


Yıldırım (2007) sınıf öğretmen adaylarının internet kullanımına ilişkin yaptıkları çalışmada haftalık daha uzun süre internet kullanan öğretmen adaylarının internet kullanımına ilişkin tutum puanlarını diğer öğretmen adaylarına göre daha yüksek bulmuştur. Ayrıca öğretmen adaylarının öğrenim durumu arttıkça ortalama puanlarının da arttığı görülmüştür. . Menzi, Çalışkan ve Çetin (2012) öğretmen adaylarının teknoloji yeterliklerini çeşitli değişkenler bakımından inceledikleri çalışmalarında interneti daha sık kullanan öğretmen adaylarının diğerlerine göre kendilerini teknoloji alanında daha yeterli gördükleri sonucuna ulaşılmıştır. Her iki ülkede de dördüncü sınıfta öğrenim gören öğretmen adaylarının dijital okuryazarlık bakımından kendilerini daha yeterli hissettikleri görülmüştür. Baş (2011) ilköğretim öğretmenlerinin eğitsel internet kullanımı öz-yeterlik inançlarını farklı değişkenler açısından incelediği çalışmasında lisan üstü düzeyde öğrenim gören öğretmenlerin eğitsel internet kullanımı özyeterlik inancını diğer öğrenim düzeyinde yer alan öğretmenlerden anlamlı derece yüksek bularak benzer sonuçlara ulaşmıştır. Yine, İnternete bağlanmak için kullanılan araç sayısı, öğretmen adaylarının dijital okuryazarlık görüşleri üzerinde etkili bir değişkendir. Kullanılan araç sayısı arttıkça öğretmen adaylarının ölçekten aldıkları ortalama puanların arttığı ve daha çok dijital araç kullanan öğretmen adaylarının bu bağlamda kendilerini daha yeterli hissettiği görülmüştür. Kişisel bir bilgisayara sahip olma durumu öğretmen adaylarının dijital okuryazarlık düzeyleri üzerinde etkili bir değişkendir. Kişisel bilgisayara sahip olan öğretmen adaylarının ortalama puanları daha yüksektir. Usta, Bozdoğan ve Yıldırım (2007) sınıf öğretmeni adaylarının internet kullanımına ilişkin yaptıkları çalışmada kendilerine ait bilgisayarı olan öğretmen adaylarının internet kullanımına ilişkin tutumlarını daha yüksek bulmuştur. Bahar, Uludağ ve Kaplan (2009) ilköğretim öğretmenlerinin bilgisayar ve internet tutumlarını inceledikleri çalışmalarında bilgisayara sahip olan öğretmenlerin bilgisayara ilişkin tutumlarında anlamlı fark bulurken internete ilişkin tutumlarında anlamlı bir fark bulamamışlardır.

Sürekli internet bağlantısına sahip olma durumu öğretmen adaylarının dijital okuryazarlık görüşleri üzerinde etkili bir değişkendir. Sürekli internet bağlantısına sahip öğretmen adaylarının dijital okuryazarlık bakımından kendini daha yeterli hissetmektedir. Bahar, Uludağ ve Kaplan (2009) ilköğretim öğretmenlerinin bilgisayar ve internet tutumlarını inceledikleri çalışmalarında evlerinde sürekli internet bağlantısı olan öğretmenlerin bilgisayara ilişkin tutumlarında anlamlı fark bulurken internete ilişkin tutumlarında anlamlı bir fark bulamamışlardır. İnternet kullanma sıklığı öğretmen adaylarının dijital okuryazarlık düzeyleri üzerinde etkili bir değişkendir. İnterneti günlük hayatında hiç kullanmayanlar dışında öğretmenlerin ölçekten aldıkları ortalama puanlar doğrusal ilerlemiş ve internet kullanma sıklıkları arttıkça kendilerini daha yeterli hissetmişlerdir. Erkek öğretmen adaylarının dijital okuryazarlık algılarının kadın öğretmen adaylarından daha olumlu olduğuna dair araştırma bulgusu aslında, dijital okuryazarlık konusunda erkekler ile kadınlar arasında, kadınlar aleyhine bir yetersizliği işaret etmektedir. Bu bulgudan hareketle, kadınlara yönelik dijital okuryazarlık eğitimlerine daha fazla öncelik verilmesine yönelik önlemlerin alınmasında yarar görülmektedir. Araştırmada yaş, cinsiyet, okuduğu sınıf ve öğretmenlik branşı gibi bireysel ve sosyokültürel değişkenlere bağlı olarak ülkeler arasında dijital becerilere sahip olma boyutunda Türkiye lehine uçurumun oluşması, ülkeler arasındaki farklılığ artırmaktadır. Dijital uçurumu azaltmaya dönük Kazakistan'daki ilgili yönetim, üniversite ve diğer kuruluşların halk eğitim merkezleri, belediyeler yoluyla ücretsiz eğitimler düzenlemeleri önerilebilir. Dijital okuryazarlık kapsamında yapılan çalışmaların ve dijital okuryazarlıkla ilgili teşvik programlar vb. Türkiye'de daha fazla olduğu görülmektedir. Ülkeler arasındaki bu farkı azaltmak için Kazakistan'da da bu çalışmalara önem verilmesi ve araştırma sayısının artırılmasının yararlı olduğu düşünülebilir.

\section{Kaynakça}

Acar, Ç. (2015). Anne ve babaların ilkokul ortaokul lise ögrencisi çocuklart ile kendilerinin dijital okuryazarlıklarına ilişkin görüşleri. (Yüksek lisans tezi). https://tez.yok.gov.tr sayfa-sından erişilmiştir.

Akkoyunlu, B., \& Soylu, M. Y. (2010). Öğretmenlerin sayısal yetkinlikleri üzerine bir çalışma. Türk Kütüphaneciliği, 24(4), 748-768. http://www.tk.org.tr/index.php/TK/ article/viewFile/449/439 sayfasından erişilmiştir.

Aydın, A. (2015). Dijital vatandaşlık. Türk Kütüphaneciliği, 29(1), 142-146. http://www.tk.org.tr/index.php/ TK/article/view/2530 sayfasından erişilmiştir. 
Bahar, H. H., \& Uludağ, E., \& Kaplan K. (2009). İlköğretim öğretmenlerinin bilgisayar ve internet tutumlarının incelenmesi. Erzincan Eğitim Fakültesi Dergisi, 11(2), 67-83. https://www.pegem.net/dosyalar/dokuman/131133-20120405162729-67-83.pdf sayfasindan erișilmiștir.

Baştuğ, M., \& Keskin, H. K. (2013). Ergenlik dönemi okuma tutum ölçeğinin Türkçeye uyarlanmas1. Turkish Studies, 8(4), 295-311. http://turkishstudies.net/Makaleler/ 780749751_16Ba\%C5\%9Ftu\%C4\%9FMuhammet-vd-edb-295-311.pdf sayfasindan erişilmiştir.

Calvani, A.,\& Fini, A., \& Ranieri, M. (2009). Models and instruments for assessing digital competence at school. Tecnologie Didattiche, 48, 39-46. Retrieved from http://docplayer.it/8696490Valutare-la-modelli-teorici-e-competenza-digitale-strumenti-applicativi-assessing-digitalcompetence-theoretical-models-and-tools.html.

Churchill, N., \& Ping, L.Ç., \& Oakley, G., \& Churchill, D. (2008). Digital storytelling and digital literacy learning. International Conference on Information Communication Technologies in Education, Island. Retrieved from https://www.academia.edu/ 2818859/Digital_storytelling_and_digital_literacy_learning.

Efimova, L., \& Grudin, J. (2008). Crossing Boundaries: Digital Literacy in Enterprises. Lankshare, C. \& Knobel, M. (Eds.). (2008). Digital Literacies (pp.203-226). Newyork: Peter Lang Publishing. Retrieved from https://books.google.com.t/books?hl=tr\&lr=\&id= doVQq67wWSwC\&oi=fnd\&pg=PA1\&dq=digital+literacy\&ots=h3X3frbG7t\&sig=RR7_dHn T9pmNjlbtFzmJf4DwHY\&redir_esc $=\mathrm{y} \# \mathrm{v}=$ onepage $\& \mathrm{q}=$ digital $\% 201$ iteracy $\& \mathrm{f}=$ false

Kalaycı, C. (2013). Dijital bölünme, dijital yoksulluk ve uluslararası ticaret. Atatürk Üniversitesi İktisadi ve Idari Bilimler Dergisi, 27(3), 145-162. http://edergi.atauni.edu.tr/atauniiibd/article/view/1025008954 sayfasından erişilmiştir.

Karasar, N. (2014). Bilimsel araştırma yöntemleri. Ankara: Nobel.

Kaşıkçı, D. N., Çağıltay, K., Karakuş, T., Kurşun, E., \& Ogan, C. (2014). Türkiye ve Avrupa'daki çocukların internet alışkanlıkları ve güvenli internet kullanımı. Eğitim ve Bilim Dergisi, 39(171), 230-243. http://egitimvebilim.ted.org.tr/index.php/EB/ article/view/1867 sayfasindan erişilmiştir.

Özsevgeç, T., Batman, T., Yazar, E., \& Yiğit, N. (2014). Öğretmen adaylarının teknolojik terim farkındalıklarının belirlenmesi. Eğitim ve Bilim Dergisi, 39(173), 235-248. http://egitimvebilim.ted.org.tr/index.php/EB/article/view/2500 sayfasından erişilmiştir.

Rantala, L., \& Suoranta, J. (2008). Digital literacy policies in the EU— Inclusivepartnership as the final stage of governmentality? Lankshare, C. \& Knobel, M.(Eds.). (2008). Digital Literacies (pp.91$117)$.

Soby, M. (2008). Digital Competence-From Education Policy to Pedagogy: The Norwegian Context. Lankshare, C. \& Knobel, M.(Eds.). (2008). Digital Literacies (pp.91-117). Newyork: Peter Lang Publishing. Retrieved from https://books.google.com.tr/books?hl=tr\&lr=\&id=doVQq67wWSwC\&oi=fnd\&pg=PA1\&dq= digital+literacy\&ots=h3X3frbG7t\&sig=RR7_dHnT9pmNjlbtFzmJf4DwHY\&redir_esc $=y \# v=0$ nepage \&q=digital $\% 20$ literacy $\& \mathrm{f}=$ false.

Timur, B., Timur, S., \&Akkoyunlu, B. (2014). Öğretmen adaylarının sayısal yetkinlik düzeylerinin belirlenmesi. Muğla Sitkı Koçman Üniversitesi Sosyal Bilimler Enstitüsü Dergisi, 33, 41-59. http://www.sobbiad.mu.edu.tr/index.php/asd/article/view/475 sayfasından erişilmiştir.

Usta, E., Bozdaoğan, A., \& Yıldırım, K. (2007). Sınıf öğretmeni adaylarının internet kullanımına ilişkin tutumlarının değerlendirilmesi. Ahi Evran Üniversitesi Kırşehir Eğitim Fakültesi Dergisi (KEFAD) 8(1), 209-22. http://kefad.ahievran.edu.tr/archieve/pdfler/ Cilt8Sayi1/JKEF_8_1_2007_209_222.pdf sayfasından erişilmiştir.

Yurdadoğ, B. U. (2013). Dijital toplumun öngördüğ̈̈ bilgi uzmanlığı. Ünak 2013 konferansında sunulmuş bildiri, Marmara Üniversitesi, İstanbul. http://kaynak.unak.org.tr/ bildiri/unak03/u03-5.pdf sayfasından erişilmiştir. 